\title{
Overall Lebanese Banks' Performance: A Risk-Return Framework
}

\author{
Viviane Y. Naïmy, (Email: vnaimy@ndu.edu.lb), Notre Dame University, Louaize - Lebanon
}

\begin{abstract}
The Lebanese commercial banks constitute the corner stone of the financing system in Lebanon. This paper analyzes the performance of the Lebanese banks in terms of profitability and risks for the period 1993 through 2002. A detailed investigation related to the structure and regulation of this industry is presented. The profitability is studied using the Du Pont equation and the overall risk of the Lebanese commercial banks is captured through the structure of the risk index suggested by Hannan and Hanweck (1998).
\end{abstract}

\section{INTRODUCTION}

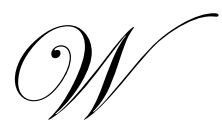

ith respect to the banking firms, there are complications to profit-maximization that the nonfinancial firm does not face. Due to the nature of financial intermediation is risky, a bank manager will need to take risks into account and maximize expected profit. Bank managers will need to take a view on what is an acceptable level of risk along with an acceptable level of profit, thus achieving an optimal riskreturn mix ${ }^{1}$.

Profitability in the banking sector has been extensively examined in developed countries. Economic and financial data published by the Central Bank of Lebanon, "Banque du Liban", BDL, and the Association of Banks in Lebanon, indicate that the Lebanese banking industry has been among the most profitable economic sectors in Lebanon in the post civil-war ${ }^{2}$. As no academic work measuring and assessing the performance of the banking sector in Lebanon has been available, this paper tries to evaluate the performance of this sector in terms of profitability and risks for the period 1993 through 2002.

The first section presents the general framework of the Lebanese banking firms. Based on ROE decomposition analysis and using the Du Pont equation, the second section explores the factors affecting the ROEs: leverage, profit margin, assets utilization, etc. The third section analyzes the Lebanese banks' riskiness and the probability of book-value insolvency. For this purpose we employ the risk index suggested by Hannan and Hanweck $^{3}$ (1988) and used by various other researchers, for example, Liang and Savage ${ }^{4}$ (1990), Eisenbeis and Kwast $^{5}$ (1991), Sinkey and Nash $^{6}$ (1993), and Sinkey and Blasko ${ }^{7}$ (2001).

\footnotetext{
${ }^{1}$ Edwards, F.R., (1977). "Managerial objectives in regulated industries: expense preference behavior in banking." Journal of Political Economy, February

${ }^{2}$ The end of the civil war was in 1990.

${ }^{3}$ Hannan, T.H. and Hanweck, G.A. (1998). "Bank Insolvency Risk and the Market for Large Certificates of Deposit," Journal of Money Credit and Banking, Vol. 20, No. 2, May, pp. 203-211.

${ }^{4}$ Liang, J.N. and Savage, D.T., (1990). “The Nonbank Activities of Bank Holding Companies,” Federal Reserve Bulletin, May, pp. $280-292$.

${ }^{5}$ Eisenbeis, R.A. and Kwast, M.L. (1991), “Are Real Estate Depositories Viable? Evidence from Commercial Banks,” Journal of Financial Services Research, March, pp. 5-24.

${ }^{6}$ Sinkey, J.F. Jr., Nash, R.C. (1993), “Assessing the Riskiness and Profitability of Credit-Card Banks,” Journal of Financial Services Research, June, Volume 7, Number 2, 127-150.

${ }^{7}$ Sinkey, J.F. Jr. and Blasko, M.(2001) "Risk-Taking and the Absence of Hedging by Real-Estate-Lending Banks, 1989-1996", Working Paper, The University of Georgia.
} 


\section{THE LEBANESE BANKING FIRM}

\section{Historical Background}

In aggregate, commercial banks in Lebanon are the dominant financial institution. They serve surplus units by offering a wide variety of deposit accounts, and they transfer deposited funds to deficit unit by providing direct loans or purchasing securities. Commercial banks serve both the private and public sectors, as their deposit and lending services are utilized by households, businesses, and government agencies. Today many commercial banks are offering a greater variety of products and services to diversify their business such as portfolio management, stockbroking and insurance services.

Lebanese banks are a special and regulated industry for the following reasons ${ }^{8}$ :

1. They provide three essential services: information intermediation, risk transformation and liquidity provision,

2. They are interdependent through the interbank market, and,

3. They are crucial for the transmission of the monetary policy.

Prior to the civil war, specifically between the 1950s and mid-1970s, the Lebanese banking industry flourished due to a strict banking secrecy law, which was introduced in 1956, the flow of the petrodollars from the Arab world, a free-market economy, and a free exchange-rate system. In fact, Lebanon was the banking center of the Middle East. At one time, 100 domestic and foreign banks operated in Lebanon in the mid-1960s, mainly in Beirut, which also flourished as the social and cultural center of the region.

The economic consequences of the civil war, which started in April 1975 and ended in October 1990, inflicted heavy casualties on the Lebanese banking sector. Specifically, hyperinflation and severe depreciation in the value of the currency led to disintermediation and declining loan values ${ }^{9}$. Although total assets of the Lebanese banking sector had increased, in nominal terms, from about $\$ 4.7$ billion in 1975 to $\$ 5.7$ billion in 1990, they had declined in real terms. Many bank customers pulled their funds out of Lebanese banks and reinvested them in banks and other financial institutions abroad. In addition, banks' profits turned to losses as loan default rates rose and capital resources were reduced dramatically and most banks became undercapitalized.

\section{Structure And Regulation}

In Lebanon, financial intermediaries are divided into five major types:

1. commercial banks,

2. banks specializing in medium and long-term credit,

3. money dealers ${ }^{10}$,

4. financial institutions ${ }^{11}$ : regarded as investment banking firms,

5. Brokerage firms.

In addition to these institutions, a number of foreign banks have representative offices in Lebanon. As of September $2003^{12}$, a total of 52 commercial banks existed in Lebanon, 10 of which were subsidiaries of foreign banks. In addition, eight banks specialize in medium- and long-term credit by providing residential mortgage loans or long-term loans to businesses secured by property. Finally, there are five brokerage institutions that trade securities on behalf of customers but do not underwrite securities.

\footnotetext{
${ }^{8}$ Swank, Job (1996), "Theories of the Banking Firm: a Review of the Literature”, Bulletin of Economic Research, Volume 38. See also Sinkey J. Jr. (2002), "Commercial Bank Financial Management in the Financial-Services Industry", Sixth Edition, Prentice Hall.

${ }^{9}$ For example, the average exchange rate depreciated from US $\$=2.29$ LP (Lebanese Pound) in 1975 to US $\$=701.76$ LP in 1990. Since 1996, the exchange rate has been fixed to US $\$=1,500 \mathrm{LP}$.

${ }^{10}$ Money dealers are primarily small retail foreign-exchange dealers and do not provide loans or take deposits.

${ }^{11}$ These firms are relatively small in size. They assist firms in obtaining long-term financing and also trade securities on behalf of customers.

${ }^{12}$ Association of Banks in Lebanon, Annual Report, 2001-2002, p.76
} 
Banks are required to have shareholders capital of at least 10 billion Lebanese pounds (US\$6.7 million) plus 250 million Lebanese pounds (US\$167,000) for each branch. Banks are required to keep as reserves with the Central Bank $25 \%$ of sight deposits denominated in LP and $15 \%$ of time deposits ${ }^{13}$ denominated in LP, and $15 \%$ on deposits denominated in US\$. Moreover, Banks are required to comply with the BIS ${ }^{14}$ risk-based-capital (RBC) requirements. In Lebanon, the present Cooke ratio is set at $12 \%$ for the Lebanese Banks. This is a ratio that banks in developed countries (and even in most developing countries) must comply with. Its minimal level is $8 \%$ (for the total capital $)^{15}$.

\section{The Present Situation: Statistical ${ }^{16}$ Description Of Profits And Balance Sheet Items}

It is worth mentioning that the number of banks covered in our study varies by year and ranges from 66 to 52 according to the following table:

\begin{tabular}{|l|c|c|c|c|c|c|c|c|c|c|}
\hline Year & 1993 & 1994 & 1995 & 1996 & 1997 & 1998 & 1999 & 2000 & 2001 & 2002 \\
\hline $\begin{array}{l}\text { Number of commercial } \\
\text { Banks = N }\end{array}$ & 65 & 65 & 66 & 64 & 62 & 52 & 59 & 54 & 53 & 52 \\
\hline
\end{tabular}

Equity, Leverage, and Safety

According to table 1 total assets grew at a compound annual rate of 22 percent from 1993 through 2001, and total equity capital grew at a compound rate of 40 percent approximately, which translates a substantial decrease in leverage and a safer structure of the Lebanese commercial banks, since EM (Equity Multiplier) declined from 46.7 (1993) to 11 (2001). This improvement is mainly due to the application of the BIS capital requirements.

Table 1: Average Total Assets-Average Equity

\begin{tabular}{|l|c|c|c|c|c|c|c|c|c|}
\hline $\begin{array}{l}\text { (in billions of Lebanese } \\
\text { pounds) }\end{array}$ & $\mathbf{1 9 9 3}$ & $\mathbf{1 9 9 4}$ & $\mathbf{1 9 9 5}$ & $\mathbf{1 9 9 6}$ & $\mathbf{1 9 9 7}$ & $\mathbf{1 9 9 8}$ & $\mathbf{1 9 9 9}$ & $\mathbf{2 0 0 0}$ & $\mathbf{2 0 0 1}$ \\
\hline Total Assets & 280.0 & 375.5 & 459.4 & 626.8 & 807.9 & 1072.2 & 1138.1 & 1315.8 & 1355.7 \\
\hline Total Equity & 6.0 & 10.0 & 26.8 & 38.6 & 56.7 & 72.9 & 77.2 & 88.2 & 89.7 \\
\hline
\end{tabular}

\section{Distribution of Assets}

The assets of the Lebanese commercial banks are divided into 16 items ${ }^{17}$. Sorted into four categories, the distribution of assets becomes as follows: (1) Treasury bills denominated in Lebanese pounds (LP), (2) Loans denominated in LP, (3) Loans denominated in foreign currencies (USD), and (4) Other assets. The first three items constitute more than $56 \%$ on average of the total assets.

\footnotetext{
${ }_{13}^{13}$ In December 2002, the BDL abolished interest paid on obligatory reserves exceeding $13 \%$.

${ }^{14}$ BIS Risk-Asset-Ratio = (total shareholders' equity - financial fixed assets)/risk weighted assets.

${ }^{15}$ In June 1999, the Basel Committee on Banking Supervision has decided to introduce a new capital adequacy framework to replace the 1988 Accord. The latter primarily concerned with minimum capital standards to cover credit risk. In the new framework, the Committee proposes to develop an explicit capital charge for other risks (such as operational risk), and interest rate risk in the banking book for banks where interest rate risks are significantly above average. Such a framework would formally take account of a wider range of actual and potential exposures.

${ }^{16}$ Our secondary data are drawn from issues of Bilanbanques.

Bilanbanques is published annually by Bank Data Financial Services in collaboration with the Association of Banks in Lebanon and is sponsored by Banque du Credit Libanais. Each issue of Bilanbanques reports data for the two years immediately preceding the issuance year. All commercial banks in Lebanon are included in our sample.

${ }^{17}$ According to Bilanbanques structure.
} 
Figure 1 shows the average ${ }^{18}$ proportion of total assets invested in each of these assets classes over the 8 years (from 1993 to 2000).

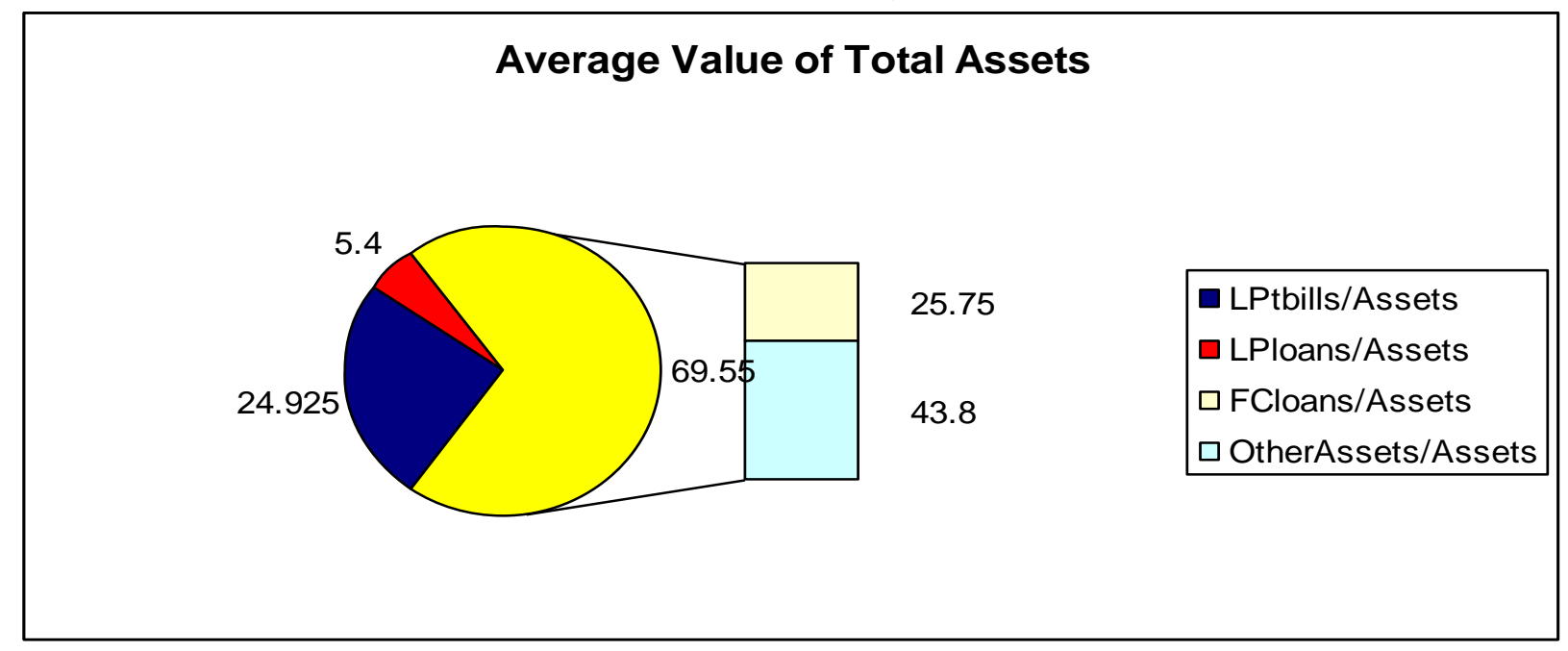

Table 2: Average Deposits and Loans of Total Assets

\begin{tabular}{|l|c|c|c|c|c|c|c|c|}
\hline In \% & $\mathbf{1 9 9 3}$ & $\mathbf{1 9 9 4}$ & $\mathbf{1 9 9 5}$ & $\mathbf{1 9 9 6}$ & $\mathbf{1 9 9 7}$ & $\mathbf{1 9 9 8}$ & $\mathbf{1 9 9 9}$ & $\mathbf{2 0 0 0}$ \\
\hline LP Loans/Assets & 4.3 & 5.6 & 6 & 5.7 & 6.1 & 5.2 & 5.6 & 4.7 \\
\hline USD Loans/Assets & 26 & 25 & 26 & 25 & 25 & 26 & 27 & 26 \\
\hline LP Deposits/Assets & 23 & 27 & 25.4 & 30 & 24 & 23.3 & 32 & 27 \\
\hline USD Deposits/Assets & 55 & 47 & 44.6 & 42.7 & 46 & 45 & 44 & 49.4 \\
\hline
\end{tabular}

\section{Sources and Uses of Funds}

According to the above table, we can depict the predominance of commercial banks in the mobilization of savings: total deposits represent on average more than $80 \%$ of banks resources. Moreover, the predominance of the deposits in the components of the money supply is evident. The proximity of deposits with respect to the components of the money supply permits to highlight the power of these institutions in the money creation process. The increase in deposits - translated by a tendency to the consolidation of (M1) and (M2) to the detriment of the fiduciary currency - is clearly reflected in the money supply ${ }^{19}$. Table 3 depicts the importance of total deposits to total assets and to the GDP in comparison with other countries. Lebanon has the highest ratio of deposits to GDP among the listed countries. It is rated number two after Japan in terms of the importance of deposits to total assets.

Furthermore, we note that one of the prominent features of the Lebanese monetary economy is the strong dollarization of deposits and credits. This dollarization remains a clear demonstration regarding the deviation of the monetary functions. The US dollar is taking the place in the collection of deposits and in the distribution of credit since the Lebanese pound was not, and is not filling its functions, mainly as a mean of payment or as a unit of account. This dollarization constitutes a serious brake to the financing of the growth and more closely, to the financing of the Lebanese industrial investment: economic agents in need of financing are indeed victims of a severe credit crunch in Lebanese pounds.

\footnotetext{
${ }^{18}$ Each average represents the average of the same category over 8 years of the average annual value of the same category, with respect to the banks size year after year.

${ }^{19}$ Naimy V. (2003), « Marchés émergents, financement des PME et croissance économique : étude du cas libanais », NDU Press, p. $218-244$.
} 
Table 3: \% of Deposits to GDP and to Total Assets in 2002

\begin{tabular}{|l|c|c|}
\hline Country & Deposits/GDP & Deposits/Total Assets \\
\hline Lebanon & $\mathbf{2 0 6 . 1}$ & $\mathbf{7 2 . 8}$ \\
\hline Japan & 122.3 & 79.7 \\
\hline Jordan & 103 & 48.7 \\
\hline Germany & 96.5 & 45.6 \\
\hline Malaysia & 92.8 & 65.2 \\
\hline Belgium & 89.9 & 35.1 \\
\hline Greece & 89.1 & 69.9 \\
\hline Korea & 83.7 & 67 \\
\hline Bahrain & 80 & 68.1 \\
\hline Egypt & 74.2 & 66.4 \\
\hline France & 64.7 & 38.5 \\
\hline USA & 63.4 & 66.9 \\
\hline Denmark & 48.1 & 22.8 \\
\hline
\end{tabular}

Sources: IFS, Cd-Rom, 2003

This dollarization maintains the activity of the depositary institutions in a traditional profile, insufficiently turned toward the financing of the economic activity ${ }^{20}$. In other words, the Lebanese bank appears like a simple transit path of deposits in Lebanese pounds toward the public sector, on the one hand, (via the subscription in treasury bills ${ }^{21}$ ) and of the deposits in foreign currencies toward the abroad banks on the other hand. In fact, the Lebanese pound is practically the "currency that serves the public sector". Deposits in LP are recycled by banks to acquire sovereign securities. The Lebanese pound became therefore a sort of "support" to the financing of the public deficits, and the dollar as the currency of the private sector: $85 \%$ of credits bestowed by banks to the private sector are drawn in USD.

Alternatively, an average loan-to-asset ratio of only 31 percent would be considered small (and unacceptable) in developed countries. Unfortunately, cash and deposits with the BDL have tremendously increased in 2002. This increase isn't but the consequence of the absorption of the liquidity in local currency by the BDL and the cash contribution of banks (at a $0 \%$ interest) to the financing of the Lebanese government in accordance with the decisions of Paris II. As a result, the share of loans allocated to the economy is decreasing annually on average by $28 \%$ since 2001, knowing that this decrease is not compensated via a direct financing through Beirut stock exchange market.

Table 4: Uses of Funds of Lebanese Commercial Banks

\begin{tabular}{|l|c|c|c|}
\hline In \% of Total Assets & $\mathbf{2 0 0 1}$ & $\mathbf{2 0 0 2}$ & September 2003 \\
\hline Cash \& Deposits at BDL & 14.8 & 15.1 & $\mathbf{2 8}$ \\
\hline Claims on Resident Private Sector & 30.9 & 28.8 & 25.9 \\
\hline Claims on Public Sector & 32.1 & $\mathbf{3 3 . 6}$ & 26.4 \\
\hline Foreign Assets & 18.1 & 18.1 & 15.7 \\
\hline Fixed Assets \& Other non-classified Assets & 4.1 & 4.4 & 4.0 \\
\hline
\end{tabular}

Source: Association of Banks in Lebanon, Annual Report, 2001-2002

\footnotetext{
${ }^{20}$ Naimy V (2004), “Financing Problems Faced By The Lebanese SMEs: An Empirical Study”. The International Business And Economics Research Journal, Volume 3, Number 1, January, p. 27-38

${ }^{21}$ The high yield on the LP treasury securities makes them an attractive investment for Lebanese banks. 21 percent of banks' total assets were invested in LP treasury securities at the end of 2000. Please refer to figure 1.
} 
Moreover, credits allocated to the private sector are characterized by their excessive concentration in terms of their distribution:

1. by banks ${ }^{22}$,

2. on the economic sectors as illustrated by figure 2 , and

3. By number of beneficiaries. $2003^{23}$.

Surprisingly, $75 \%$ of total loans were distributed to only $4.2 \%$ of total number of beneficiaries as of March

Figure 2: Distribution of Loans on the Economic Sectors as of March 2003

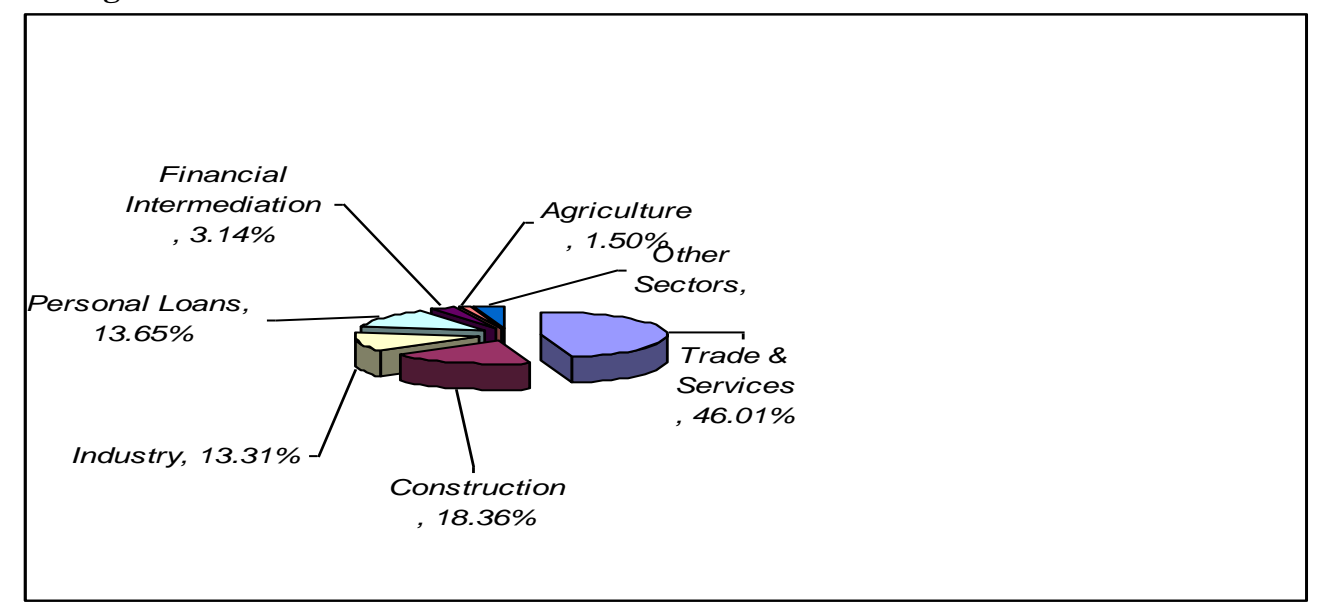

Off-Balance Sheets Activities

Off-balance sheets activities (OBSAs), which for Lebanese banks include guarantees and standby letters of credits (the largest of the items), documentary and commercial letters of credit, fiduciary deposits, and interest-rate swaps, have not kept pace with the growth of total assets. As a percent of total assets, OBSAs have varied between 10 and 13.5 percent from 1993 through 2002.

\section{PROFITABILITY ANALYSIS}

\section{The ROE Model}

The headlines attest to return on Assets ROA's prominence as the accounting measure of overall bank performance and to the critical importance of loan quality in determining bank performance. Similarly, Return On Equity $(\mathrm{ROE})^{24}$ measures profitability but from the shareholder's perspective. Accounting ROE measures bank accounting profits per dollar of book equity capital. It is defined as net income divided by average equity. It can be decomposed into a leverage factor (EM) and ROA:

$\mathrm{ROE}=\mathrm{ROA} X \mathrm{XM}$

\footnotetext{
${ }^{22}$ In 2002, the top 20 banks have allocated $88 \%$ of total loans.

${ }^{23}$ Association of Banks in Lebanon, Annual Report, 2001-2002

${ }^{24}$ ROE should not be confused with investment profitability (or return) as measured by dividends and stock price appreciation.
} 
Where:

ROA = Net Income/ Average of Total Assets. It measures bank profit per dollar of assets

$\mathrm{EM}=$ Average Assets/Average Equity. It provides a gauge of a bank's leverage ${ }^{25}$ or the dollar amount of assets pyramided on the bank's base of equity capital (A/E). The second stage of ROE decomposition analysis (Du Pont analysis) splits ROA into:

1. $\quad$ Profit margin (PM), and

2. Asset utilization (AU)

$\mathrm{ROA}=\mathrm{PM} X \mathrm{AU}$

Where:

$\mathrm{PM}=$ Net income $/$ Total Revenue ${ }^{26}$. It reflects profits per dollar of sales.

$\mathrm{AU}=$ Total Revenue / Average Total Assets. It expresses sales per dollar of assets.

By splitting ROA we can pinpoint the variables that underlie ROA performance.

The ROE model contains three alternative measures of profitability ${ }^{27}$ : ROE, ROA, and PM. Its primary shortcoming as a measure of bank performance is that ROE can be high because a bank has inadequate equity capital. In addition, a bank with negative book equity ${ }^{28}$ and negative profits would show a positive return on equity. By splitting ROE, this dilemma can be resolved. Thus, the ROA is the preferred accounting measure of overall bank performance. It measures how profitable all of a bank's on-balance sheet assets are employed.

Components Of The ROE Model For Lebanese Commercial Banks: 1997 - 2002

Table 5: ROE Decomposition Analysis

\begin{tabular}{|l|c|c|c|c|c|}
\hline YEAR & PM & AU & EM & ROE & ROA \\
\hline 1997 & 0.127 & 0.103 & 10.345 & 0.136 & 0.013 \\
\hline 1998 & 0.118 & 0.103 & 10.533 & 0.127 & 0.012 \\
\hline 1999 & 0.091 & 0.099 & 10.691 & 0.096 & 0.009 \\
\hline 2000 & 0.069 & 0.099 & 10.900 & 0.074 & 0.007 \\
\hline 2001 & 0.077 & 0.087 & 11.059 & 0.074 & 0.007 \\
\hline 2002 & 0.069 & 0.078 & 10.272 & 0.055 & 0.005 \\
\hline
\end{tabular}

ROE for all Lebanese banks declined from13\% in 1997 to 5.5\% in 2002. In fact, the years 1997 through 1999 were banner years for the Lebanese banking industry as record profits were earned due to the high subscription in sovereign securities providing abnormally high yields ${ }^{29}$. During the same period, ROA were always above $1 \%{ }^{30}$ and ROE were driven by a high multiplier always exceeding the level of 10. However, starting 2000, AU weakened on average by $7.2 \%$ and PM declined by $8 \%$ on average which was reflected on an unacceptable ROA less than the benchmark of $1 \%$.

\footnotetext{
${ }^{25}$ For example an EM of 10 implies an equity-to-asset ratio of $1 / 10$ or $10 \%$, or a debt-to-asset ratio of $90 \%$.

${ }^{26}$ Total revenue $=$ interest revenue plus noninterest revenue.

${ }^{27}$ Sinkey J. Jr. (2002), “Commercial Bank Financial Management In The Financial-Services Industry”, Sixth Edition, Prentice Hall, p. 132.

${ }^{28}$ Book insolvency

${ }^{29}$ Interest rates served on government bonds in LP reached $40 \%$.

${ }^{30}$ With respect to a benchmark ROA of one percent as a minimum performance standard, based on the US experience (excluding the ten largest banks).

Sinkey J. Jr. (2002), “Commercial Bank Financial Management In The Financial-Services Industry”, Sixth Edition, Prentice Hall, p. 129-133.
} 
The positive side of the decrease in ROE was due to large increases in the ratio of shareholders equity to total assets for most banks. Banque du Liban put pressure on banks to increase equity capital and introduced capitalstructure rules on banks during this period.

Since information on loan quality is insufficient in Lebanon, and loan quality or the lack of it is the primary driver of bank earnings and return on assets, we are not able to analyze this item for Lebanese commercial banks. The only indicator we have for loan quality is the "provision for loan losses ${ }^{31}$ " (PLL). As a percent of total loans, the loan-loss reserve is on average $16 \%$. This ratio is considered to be high with respect to the low level of lending. However, Lebanese banks keep always high level of reserves relative to the loans they do allocate ${ }^{32}$. In general, Lebanese banks have a conservative behavior.

The Lebanese banking industry showed acceptable profitability performance. However, the decrease in return since 2001 is mainly due to the change in the structure of the banks' assets as mentioned in table 4 . A serious commitment to improve the following factors is required:

1. Asset reallocation

2. Loan quality

3. Generation of fees and other noninterest income

4. Operating efficiency

\section{MEASURING THE RISK INDEX FOR LEBANESE BANKS}

If we want to capture the overall risk of a bank, the variability of ROA provides a comprehensive measure that reflects not only credit risk but also interest rate risk, liquidity risk, operating risk, and any other risk that is realized in bank earnings. The standard deviation of $\mathrm{ROA}^{33}$ is a good measure of the variability of ROA.

Combining ROA, EM, and the standard deviation of ROA provides the risk index. The empirical form of this index is:

$\mathrm{RI}^{34}=[\mathrm{E}(\mathrm{ROA})+\mathrm{CAP}] / \sigma_{\mathrm{ROA}}$

Where:

$\mathrm{E}(\mathrm{ROA})=$ expected return on assets

$\mathrm{CAP}=\mathrm{EM}^{-1}$

$\sigma_{\mathrm{ROA}}=$ the standard deviation of ROA

RI, expressed in units of standard deviations of ROA, is a measure of how much a bank's accounting earnings can decline until it has a negative book value.

The probability of book value insolvency ${ }^{35}$, П, expresses the probability of book value insolvency which significantly differs from market value solvency. In terms of RI,

$\Pi=1 /\left[2(\mathrm{RI})^{2}\right]$

The RI equation is an appealing risk measure because it includes ROA, the most widely accepted accounting measure of overall bank performance, the variability of ROA which is a standard measure of risk in financial economics, and book capital adequacy which represents an industry standard for bank safety and soundness.

\footnotetext{
${ }^{31}$ It's worth mentioning that PLL is not a noncash outlay but the actual reserve account.

${ }^{32}$ Association of Banks in Lebanon. Annual Reports: 1995-2003.

${ }^{33}$ Over time for an individual bank and cross-sectionally for a group of banks at a point in time.

${ }^{34}$ This risk index is due to Hannan and Hanweck (1988).

${ }^{35}$ As derived by Hannan and Hanweck (1998).
} 
Table 6: RI of the Lebanese Commercial Banks and Pr. $(\mathrm{BVE}<0)$

\begin{tabular}{|l|c|c|c|c|c|c|}
\hline YEAR & $\mathbf{1 9 9 7}$ & $\mathbf{1 9 9 8}$ & $\mathbf{1 9 9 9}$ & $\mathbf{2 0 0 0}$ & $\mathbf{2 0 0 1}$ & $\mathbf{2 0 0 2}$ \\
\hline CAP & 0.096664 & 0.094943 & 0.093533 & 0.091743 & 0.090426 & 0.097355 \\
\hline S ROA & 2.13203 & 1.7018 & 1.25693 & 1.27386 & 1.16939 & 1.44597 \\
\hline RI=[E(ROA)+CAP]/S(ROA) & 5.223396 & 6.366364 & 8.189247 & 7.759323 & 8.365556 & 7.120131 \\
\hline Pr. $(\mathrm{BVE}<0)$ & 0.009163 & 0.006168 & 0.003728 & 0.004152 & 0.003572 & 0.004931 \\
\hline
\end{tabular}

Table 6 shows that with relatively strong capital position, stable earnings, and accepted E(ROA), Lebanese banks have moderately high RI. Moreover, the probability of book-value insolvency is low - less than one-half of 1 percent on average. The two measures of risk, the risk index and the standard deviation of ROA indicate that Lebanese banks became safer in 1999 than in 1997 and before ${ }^{36}$. However this safety declined in 2002 after it has reached its peak in 2001 when banks were compelled to abide with the new BIS risk-based-capital requirement of $12 \%^{37}$ instead of $10 \%^{38}$. As of December 2003, the capital adequacy ratio of the Lebanese commercial banks was $19 \%$ on average. This high ratio is due to the low weights associated to risk categories corresponding to loans allocated to the public sector and deposits held with the $\mathrm{BDL}^{39}$.

\section{CONCLUSION}

The Lebanese banking system is characterized by a healthy banking management, a relatively strong capitalization and a rigorous control. The growth rate of the banking economic activity knew a slowdown since the beginning of the year 2000. In spite of this slowdown, the growth rate of the banking activity exceeded the average growth of the GDP, reflecting consequently the added value generated by this industry. Lebanese banks play an important role in the financing of the economy. However, one of the prominent features of the Lebanese monetary economy is the strong dollarization of deposits and credits. Lebanese banks appear like intermediary transferring deposits in LP and in USD to the public sector to finance an intolerable public deficit absorbing a fundamental part of local financial resources. Unexpected movements in interest rates or any political or regional shock may depress banks' profitability and thereby threaten their solvency. As a result, the general performance of the Lebanese banking system is highly correlated with the economic situation of the country which is suffering from a severe structural imbalances illustrated by a total debt exceeding $185 \%$ of the GDP, an increasing deficit, and a permanent deficit in the balance of trade. Lebanese banks are a strong shock absorber given their strength in terms of risk and return but without a drastic change of the present monetary and fiscal policies, the performance of Lebanese banks may be seriously jeopardized.

\section{BIBLIOGRAPHY}

1. “Association of Banks in Lebanon”. Annual Reports: 1995-2003.

2. Avery, R. and Berger A., (1991). "Loan Commitments and Bank Risk Exposure", Journal of Banking and Finance, September

3. Basel Committee on Banking Supervision (1999). “A New Capital Adequacy Framework”, Basel, June.

4. Bilanbanques, (1993-2002). Bank Data Financial Services.

5. Crenshaw A. (1989). "The Role of Deposits in Loan Pricing”, Journal of Commercial Bank Lending, June

6. Edwards, F.R. (1977). "Managerial objectives in regulated industries: expense preference behavior in banking." Journal of Political Economy, February.

7. Eisenbeis, R.A. and Kwast, M.L. (1991). "Are Real Estate Depositories Viable? Evidence from Commercial Banks," Journal of Financial Services Research, March.

\footnotetext{
${ }^{36}$ For example in 1993 and 1994 the RI was 2.36 and 2.52 respectively.

${ }^{37}$ Imposed by the local authorities

${ }^{38}$ Before 2000 , the cooke ratio in Lebanon was $8 \%$.

${ }^{39}$ Since cash and equivalents exceed $28 \%$ of total assets, they are considered as risk-free assets $(\mathrm{w}=0)$, and more than $50 \%$ of total loans are allocated to the public sector with also very low risk weights.
} 
8. Hannan, T.H. and Hanweck, G.A. (1998). "Bank Insolvency Risk and the Market for Large Certificates of Deposit," Journal of Money Credit and Banking, Vol. 20, No. 2, May.

9. Heffeman, Shelagh (1996). Modem Banking in Theory and Practice, Chichester, England: John Wiley and Sons.

10. James, Christopher M. and Clifford W. Smith (1994). Studies in Financial Institutions: Commercial Banks, New York. McGraw- Hill Inc.

11. Liang, J.N. and Savage, D.T., (1990). "The Nonbank Activities of Bank Holding Companies," Federal Reserve Bulletin, May.

12. Naïmy V. (2003). Marchés émergents, financement des PME et croissance économique: étude du cas libanais, NDU Press.

13. Naïmy V. (2004). "Financing Problems Faced By The Lebanese SMEs: An Empirical Study". The International Business and Economics Research Journal, Volume 3, Number 1, January.

14. Santomero, A.M (1984). "Modelling the Banking Firm”, Journal of Money, Credit and Banking, November.

15. Sinkey J. Jr. (2002). Commercial Bank Financial Management in the Financial-Services Industry, Sixth Edition, Prentice Hall.

16. Sinkey, J.F. Jr. and Blasko, M. (2001). "Risk-Taking and the Absence of Hedging by Real-Estate-Lending Banks, 1989-1996", Working Paper, The University of Georgia.

17. Sinkey, J.F. Jr., Nash, R.C. (1993). "Assessing the Riskiness and Profitability of Credit-Card Banks," Journal of Financial Services Research, June, Volume 7, Number 2.

18. Swank, Job (1996). "Theories of the Banking Firm: a Review of the Literature", Bulletin of Economic Research, Volume 38. 